\title{
Bromeliad-inhabiting mosquitoes in an urban botanical garden of dengue endemic Rio de Janeiro. Are bromeliads productive habitats for the invasive vectors Aedes aegypti and Aedes albopictus?
}

\author{
Márcio Goulart Mocellin1, Taynãna César Simões², Teresa Fernandes Silva do Nascimento1, \\ Maria Lucia França Teixeira ${ }^{3}$, Leon Philip Lounibos ${ }^{4}$, Ricardo Lourenço de Oliveira' ${ }^{1}+$

\begin{abstract}
${ }^{1}$ Laboratório de Transmissores de Hematozoários, Instituto Oswaldo Cruz-Fiocruz, Av. Brasil 4365, 21045-900 Rio de Janeiro, RJ, Brasil ${ }^{2}$ Departamento de Epidemiologia e Métodos Quantitativos em Saúde, Escola Nacional de Saúde Pública-Fiocruz, Rio de Janeiro, RJ, Brasil ${ }^{3}$ Laboratório de Fitossanidade, Instituto de Pesquisa Jardim Botânico do Rio de Janeiro, Rio de Janeiro, RJ, Brasil ${ }^{4}$ Florida Medical Entomology Laboratory, University of Florida, Vero Beach, FL, USA
\end{abstract}

Immatures of both Aedes aegypti and Aedes albopictus have been found in water-holding bromeliad axils in Brazil. Removal of these plants or their treatment with insecticides in public and private gardens have been undertaken during dengue outbreaks in Brazil despite uncertainty as to their importance as productive habitats for dengue vectors. From March 2005-February 2006, we sampled 120 randomly selected bromeliads belonging to 10 species in a public garden less than $200 \mathrm{~m}$ from houses in a dengue-endemic neighborhood in Rio de Janeiro. A total of 2,816 mosquito larvae and pupae was collected, with an average of 5.87 immatures per plant per collection. Culex (Microculex) pleuristriatus and Culex spp of the Ocellatus Group were the most abundant culicid species, found in all species of bromeliads; next in relative abundance were species of the genus Wyeomyia. Only two individuals of Ae. aegypti (0.07\%) and five of Ae. albopictus (0.18\%) were collected from bromeliads. By contrast, immatures of Ae. aegypti were found in manmade containers in nearly $5 \%$ of nearby houses. These results demonstrate that bromeliads are not important producers of Ae. aegypti and Ae. albopictus and, hence, should not be a focus for dengue control. However, the results of this study of only one year in a single area may not represent outcomes in other urban localities where bromeliads, Ae. aegypti and dengue coincide in more disturbed habitats.

Key words: Aedes aegypti - Aedes albopictus - dengue - bromeliad mosquitoes - Bromeliaceae

Although domestic Aedes aegypti has a clear preference for man-made larval habitats, its immatures may be found in natural containers such as water-containing axils of bromeliads growing in both modified and semimodified environments of the Americas (Peryassú 1908, Forattini \& Marques 2000, Marques et al. 2001, Cunha et al. 2002, O'Meara et al. 2003, Fouque et al. 2004, Varejão et al. 2005, Maciel-de-Freitas et al. 2007). Bromeliads are popular ornamental plants and often used in public and private gardens. The abundance of bromeliads where dengue is endemic has been construed to represent a threat to dengue vector control (Natal et al. 1997, Forattini et al. 1998, Forattini \& Marques 2000). Even though Ae. aegypti immatures have been found in such plants only occasionally (Cunha et al. 2002, O’Meara et al. 2003, Maciel-de-Freitas et al. 2007, David et al. 2009) and few studies have evaluated the productivity of ornamental bromeliads for Ae. aegypti (Frank et al. 1988) compared to other larval habitats, bromeliads have been arbitrarily insecticide-treated, removed or incinerated during some dengue epidemics,

Financial support: CNPq (501529/2003-9)

+ Corresponding author: lourenco@ioc.fiocruz.br

Received 30 October 2009

Accepted 3 December 2009 such as in outbreaks in Rio de Janeiro (RJ) in 20012002 and 2008 (Lourenço-de-Oliveira 2008, JR Duarte, unpublished observations).

Herein we describe results of field surveys of the identity and frequency of bromeliad-inhabiting mosquitoes in bromeliads in a public garden in a dengue-endemic area of RJ and demonstrate that native species of Culex and Wyeomyia mosquitoes were the most abundant culicids and that the invasive species Ae. aegypti and Aedes albopictus were recovered rarely from these plants, which should not be of concern for dengue control.

\section{MATERIALS AND METHODS}

One hundred and twenty bromeliads belonging to 10 species cultivated in the ground at a public garden [Jardim Botânico do Rio de Janeiro (JBRJ); 2258’04”S $43^{\circ} 13^{\prime} 44^{\prime \prime} \mathrm{W}$ ] were randomly selected, labeled and numbered. The selected bromeliads were growing in the open, less than $200 \mathrm{~m}$ from houses in the dengue-endemic neighborhood of Gávea. One of the borders of JBRJ is an ecotone between the garden environment and secondary rain forest, but the sampled bromeliads were located at the other edge, in a modified environment where the garden is contiguous to houses. The bromeliads were exposed to natural rainfall and were not treated with insecticide during the sampling period nor in the previous 10 months. Labeled bromeliads were divided into three groups, each composed of an equal number of specimens 
belonging to a single species. The number of specimens per group (Table I) varied according to the population density of the bromeliad species at JBRJ. From March 2005-February 2006, bromeliads of all groups were sampled every three months. For instance, bromeliads from group one were sampled in March, June, September and December 2005, while sampling from those of group two began in April 2005, and so on. At each sampling, all the water impounded by all the leaf axils of a labeled bromeliad was aspirated according to Lozovei and Silva (1999), measured $(\mathrm{mL})$ and taken to the laboratory for mosquito identifications using keys for morphological characters of immature stages or emerged adults provided by Lane and Whitman (1951), Corrêa and Ramalho (1956), Coutinho and Forattini (1962), Forattini and Toda (1966), Cotrim and Galati (1977), Consoli and Lourenço-de-Oliveira (1994) and Motta and Lourenço-de-Oliveira (2005). The number of axils holding water and whether the sampled plant was in the sun or partial or total shade was recorded at every sampling. Daily rainfall was obtained from the meteorological station at JBRJ.

For statistical analyses we used the programs SPSS, Minitab and Statistica 6.0. For purposes of correlation analyses, samples from the same plant separated by three months were considered as independent. Spearman's correlations (significance level: $\mathrm{p}<0.05$ ) were used to evaluate relationships between total mosquito abundance and (i) the number of bromeliad leaf axils holding water and (ii) the total amount of water (mL). The same test was applied to calculate the correlations between abundances of individual mosquito species and (i) the amount of water held in the bromeliad's leaf axils and (ii) rainfall. Nonparametric Kruskal-Wallis tests $(\mathrm{p}<0.05)$ were used to analyze variations in mosquito abundance in each bromeliad species, in relation to their location in open-sunlit, shaded or partially shaded sites and amount of water held in each sunlit bromeliad. Ae. aegypti and Ae. albopictus were not considered in statistical analyses because of their rarity in collections. A Friedman's test was used to analyze effects of bromeliad location (sun light vs. shade) in which bromeliad species was considered a block effect.

\section{RESULTS AND DISCUSSION}

A total of 2,816 immature mosquitoes was collected. Species of Culex (77.2\%) and Wyeomyia (21.4\%) were the most abundant bromeliad mosquitoes (Table II). Culex (Microculex) pleuristriatus was by far the most common species (42.5\%), followed by species of Culex belonging to the Ocellatus Group (34.7\%).

Only two larvae of Ae. aegypti $(0.07 \%$ of total mosquitoes) and five of Ae. albopictus (0.18\%) were collected in more than one year of sampling of the bromeliads. This result suggests that larvae of these species are inferior competitors with native bromeliad-inhabiting species or that adult females prefer not to oviposit in bromeliads. Manmade containers (e.g., drains, plant vases, plastic basins, tires, water tanks) in nearby houses were consistently positive for both species of Aedes, particularly Ae. aegypti. The house infestation index for Ae. aegypti nearby was found to be as high as $5 \%$ in a survey conducted simultaneous to our sampling of bromeliads in 2006 (Secretaria Municipal de Saúde, unpublished observations). During the 2001 and 2008 dengue epidemics in RJ, it was hypothesized that bromeliads in public gardens and even native bromeliads growing in the ecotone between the natural and modified environments would be productive and persistent Ae. aegypti habitats from which emerged adults would invade houses and recolonize manmade larval habitats. Our findings suggest just that this concern is unfounded, as only two larvae and no pupae of Ae. aegypti were found in a single bromeliad compared to high infestations in surrounding houses. Varejão et al. (2005) did not detect

TABLE I

Sampled bromeliads and collected mosquitoes at Jardim Botânico do Rio de Janeiro from March 2005-February 2006

\begin{tabular}{|c|c|c|c|c|}
\hline Bromeliads & $\begin{array}{l}\text { Number of sampled bromeliad } \\
\text { (number examined per sampling) }\end{array}$ & $\begin{array}{l}\text { Collected } \\
\text { mosquitoes } \\
\text { n }\end{array}$ & $\begin{array}{l}\text { Mean of water } \\
\text { (SD) }\end{array}$ & Species of mosquito ${ }^{a}$ \\
\hline Alcantarea imperialis (Carrière) Harms & $3(1)$ & 130 & 7600 (2.758) & $2,4,7,10,13,14$ \\
\hline Aechmea blanchetiana (Baker) L. B. Sm. & $15(5)$ & 878 & 351 (346) & $3,4,7,10,11,13,14$ \\
\hline Aechmea lingulata (L.) Baker & $9(3)$ & 228 & $158(206)$ & $4,7,10,11,12,13$ \\
\hline Aechmea pectinata Baker & $15(5)$ & 105 & $31(45)$ & $3,10,11$ \\
\hline Billbergia nana E. Pereira & $21(7)$ & 40 & $11(17)$ & $10,11,13,14$ \\
\hline Edmundoa lindenii (Regel) Leme & $9(3)$ & 286 & $114(136)$ & $4,7,9,10,11,13,14$ \\
\hline Neoregelia compacta (Mez) L. B. Sm. & 21(7) & 109 & $61(63)$ & $1,3,7,11,12,13,14$ \\
\hline Neoregelia cruenta (R Graham) L. B. Sm. & $9(3)$ & 247 & 139 (107) & $3,4,7,9,10,11,13$ \\
\hline Neoregelia johannis (Carrière) L. B. Sm. & $9(3)$ & 450 & 293 (339) & $2,3,4,7,10,11,12,13,14$ \\
\hline Quesnelia quesneliana (Brongniart) L. B. Sm. & $9(3)$ & 341 & $173(123)$ & $2,3,7,10,11,12,14$ \\
\hline Total & $120(40)$ & 2816 & $315(1.250)$ & \\
\hline
\end{tabular}

a: see Table II. 


\section{TABLE II}

Abundances of mosquito species collected in 10 bromeliad species at Jardim Botânico do Rio de Janeiro from March 2005-February 2006

\begin{tabular}{lccc}
\hline & Species & $\mathrm{n}$ & $\%$ \\
\hline 1 & Ae. (Stg.) aegypti (Linnaeus) & 2 & 0.07 \\
2 & Ae. (Stg.) albopictus (Skuse) & 5 & 0.18 \\
3 & Cx. (Mel.) nigrimacula Lane \& Whitman & 19 & 0.67 \\
4 & Cx. (Mel.) ocellatus Theobald & 20 & 0.71 \\
5 & Culex spp Ocellatus Group & \\
& & 939 & 33.35 \\
6 & Cx. (Mcx.) carioca Lane \& Whitman & 2 & 0.07 \\
7 & Cx. (Mcx.) pleuristriatus Lutz & 1,195 & 42.44 \\
8 & Cx. (Mcx.) stonei Lane \& Whitman & 1 & 0.04 \\
9 & Runchomyia sp. & 5 & 0.18 \\
10 & Wy. (Pho.) incaudata (Root) & 394 & 13.99 \\
11 & Wy. (Pho.) pilicauda (Root) & 89 & 3.16 \\
12 & Wy. (Pho.) theobaldi (Lane \& Cerqueira) & 29 & 1.03 \\
13 & Wy. (Spi.) forcipenis (Lourenço-de-Oliveira \& Silva) & 91 & 3.23 \\
14 & Toxorhynchites sp. & 25 & 0.89 \\
Total & & 2,816 & 100 \\
\hline
\end{tabular}

$a$ : immature forms of $C x$. nigrimacula or $C x$. ocellatus could not be separated by keys.

any relationship between Ae. aegypti occurrence in native bromeliads on rock slopes and the Stegomyia indices in adjacent areas in the state of Espírito Santo, Brazil. Marques et al. (2001) found more Ae. albopictus larvae in exotic urban bromeliads than in native or periurban ones in the state of São Paulo and considered bromeliads to be of secondary importance as larval habitats for Ae. albopictus compared to artificial containers.

The number of collected immatures and species composition varied according to bromeliad species (Table I). Around $31 \%$ of all mosquitoes were found in Aechmea blanchetiana, Neoregelia compacta, Neoregelia cruenta and Neoregelia johannis, which showed the greatest diversity of mosquito species composition in their axils. Species of Wyeomyia were the most frequent mosquitoes in $N$. compacta (68.8\%) and Billbergia nana (50\%).

With mosquito species designated as blocks, a Friedman's test indicated a marginally significant effect of bromeliad location on mosquito abundance $\left(\chi^{2}=5.64\right.$, $\mathrm{DF}=2, \mathrm{p}=0.06$ ) (Fig. 1). However, Lopez (1997) (apud Lopez et al. 1998) have suggested that shade favors faunal abundance, species composition and richness in the leaf axils of bromeliads.

The number of immature mosquitoes collected per sampled bromeliad was positively correlated with the number of axils per bromeliad (Spearman's $\rho=0.234$, $\mathrm{p}<0.0001, \mathrm{n}=480$ ) (Fig. 2) as well as with the amount of water held by the plant $(\rho=0.529, \mathrm{p}<0.0001, \mathrm{n}=468)$ (Fig. 3). When considering mosquito species separately, positive correlations were found between the amount of water in the plant and the number immatures of: Wyeo-

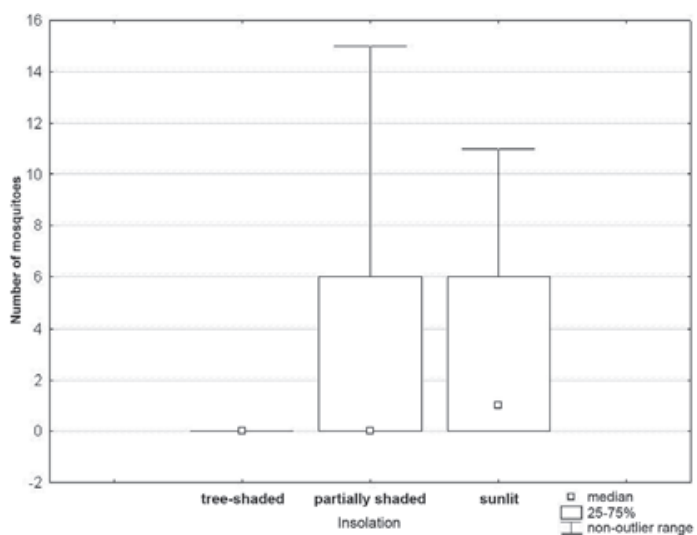

Fig. 1: box-plot of numbers of immature mosquitoes collected in treeshaded, partially shaded and sunlit bromeliads at Jardim Botânico do Rio de Janeiro from March 2005-February 2006.

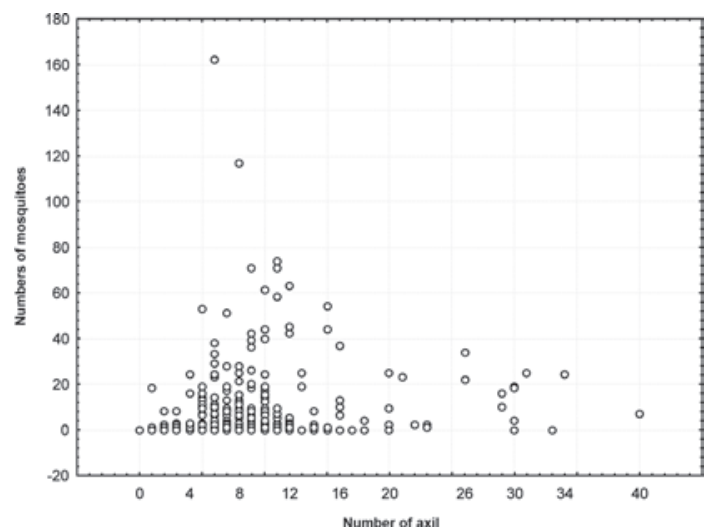

Fig. 2: dispersion analysis of number of immature mosquitoes and leaf axils in bromeliads at Jardim Botânico do Rio de Janeiro from March 2005-February 2006.

myia incaudata $(\rho=0.495, \mathrm{p}<0.0001, \mathrm{n}=480), C x$. pleuristriatus $(\rho=0.438, \mathrm{p}<0.0001, \mathrm{n}=480)$, Wyeomyia pilicauda $(\rho=0.280, p<0.0001, n=480)$, Culex ocellatus $(\rho=0.238, \mathrm{p}<0.0001, \mathrm{n}=480)$, Culex nigrimacula ( $\rho=0.193, p<0.0001, n=480)$, Wyeomyia theobaldi $(\rho=0.149, \mathrm{p}=0.001, \mathrm{n}=480)$ and Wyeomyia forcipenis $(\rho=0.136, \mathrm{p}=0.003, \mathrm{n}=480)$. The number of mosquitoes found in the huge bromeliad Alcantarea imperialis was not considered for these analyses, because mosquito numbers differed from those in the other plants and the amount of water held by A. imperialis was usually 10-20 folds greater than that held by the other species (Table I). The median number of mosquitoes collected in A. imperialis was among the highest (Fig. 4) reported among bromeliad species and the number of mosquitoes collected per sample varied much less in this huge bromeliad species than in most of other plants, such as A. blanchetiana and species of genus Neoregelia (Fig. 4).

Although rainfall reported in the first two trimesters (Mar-Aug) of the sampling period was lower than 


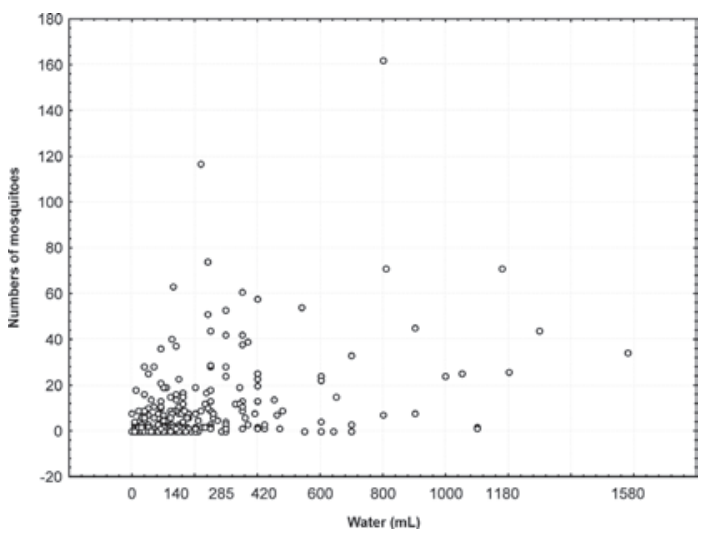

Fig. 3: dispersion analysis of number of immature mosquitoes and water held in bromeliads at Jardim Botânico do Rio de Janeiro from March 2005-February 2006. Data from the huge bromeliad Alcantarea imperialis were not considered.

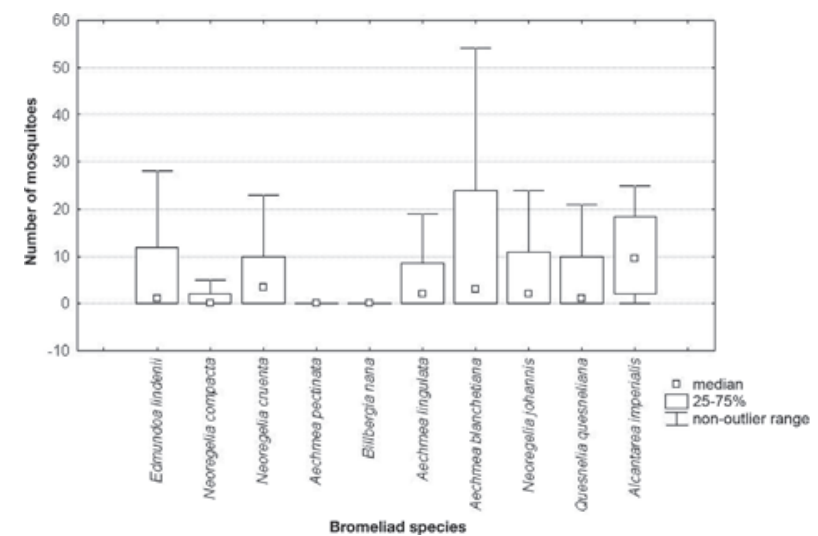

Fig. 4: box-plot of numbers of immature mosquitoes collected in bromeliad species at Jardim Botânico do Rio de Janeiro from March 2005-February 2006. in the third and fourth trimesters (Sept-Feb), the number of mosquitoes per collection in all bromeliads did not differ significantly among trimesters (KruskalWallis $\mathrm{H}=3.17, \mathrm{p}=0.366$ ) (Fig. 5). Correlations between lagged rainfall and mosquito abundances were analyzed, following Lourenço-de-Oliveira et al. (2004). Significant correlations $(n=480, p \leq 0.05)$ were observed between rainfall in the first week before collections for abundances of $C x$. nigrimacula $(\rho=0.630)$ and Wy. pilicauda $(\rho=0.585)$.

The five most common mosquito species occurred together in the same sample significantly more often than predicted by chance (Table III). The absence of significant negative correlations in the associations of species suggests that females of these species are using similar clues for oviposition in favorable bromeliads. Species of the genus Wyeomyia and Culex have frequently been found together in bromeliads (Marques et al. 2001, Yanoviak et al. 2006). Interestingly, the frequency of these Culex species in the cultivated bromeliads at JBRJ is similar to values reported in native plants in the natural environment elsewhere in Brazil (Corrêa \& Ramalho 1956, Lourenço-de-Oliveira et al. 1986, Marques et al. 2001, Silva et al. 2004).

Some mosquitoes, such as Culex (Microculex) and Culex belonging to the Ocellatus Group and some Wyeomyia (Phoniomyia) species seem to be intimately associated with bromeliads in the Neotropical region. Bromeliad-specific Wyeomyia spp have been shown in Florida to inhibit the growth and survivorship of Ae. albopictus co-occurring in axils of Bilbergia pyramidalis (Lounibos et al. 2003). Interspecific competition with bromeliad-specialist species may make this habitat less suitable for the container generalist species Ae. albopictus and Ae. aegypti in JBRJ.

Our results and previous works (Marques et al. 2001, Cunha et al. 2002, Maciel-de-Freitas et al.

TABLE III

Interspecific tests of association by Spearman's rho (top) and Hurlbert’s C8

\begin{tabular}{|c|c|c|c|c|}
\hline Species & $\begin{array}{c}\text { Culex spp } \\
\text { Ocellatus Group }\end{array}$ & Wyeomyia incaudata & Wyeomyia pilicauda & Wyeomyia forcipecis \\
\hline $\begin{array}{l}\text { Cx. (Microculex) } \\
\text { pleuristriatus }\end{array}$ & $\begin{array}{c}0.220^{a} \\
0.089^{a} \\
(<0.001)^{a}\end{array}$ & $\begin{array}{c}0.277^{a} \\
0.343^{a} \\
(<0.001)^{a}\end{array}$ & $\begin{array}{c}0.108^{a} \\
0.088^{a} \\
(0.017)^{a}\end{array}$ & $\begin{array}{c}0.033 \\
0.020 \\
(0.471)\end{array}$ \\
\hline $\begin{array}{l}C x . \text { spp } \\
\text { Ocellatus Group }\end{array}$ & & $\begin{array}{c}0.208^{a} \\
0.590^{a} \\
(<0.001)^{a}\end{array}$ & $\begin{array}{c}0.089 \\
0.158 \\
(0.051)\end{array}$ & $\begin{array}{c}-0.050 \\
-1 \\
(0.278)\end{array}$ \\
\hline Wy. incaudata & & & $\begin{array}{c}0.283^{a} \\
0.167^{a} \\
(<0.001)^{a}\end{array}$ & $\begin{array}{c}0.097^{a} \\
0.041^{a} \\
(0.034)^{a}\end{array}$ \\
\hline Wy. pilicauda & & & & $\begin{array}{c}0.118^{a} \\
0.088^{a} \\
(0.010)^{a}\end{array}$ \\
\hline
\end{tabular}

numbers in parentheses are significance levels for the Spearman's test. $a$ : association analyses significant at p $<0.05$. 


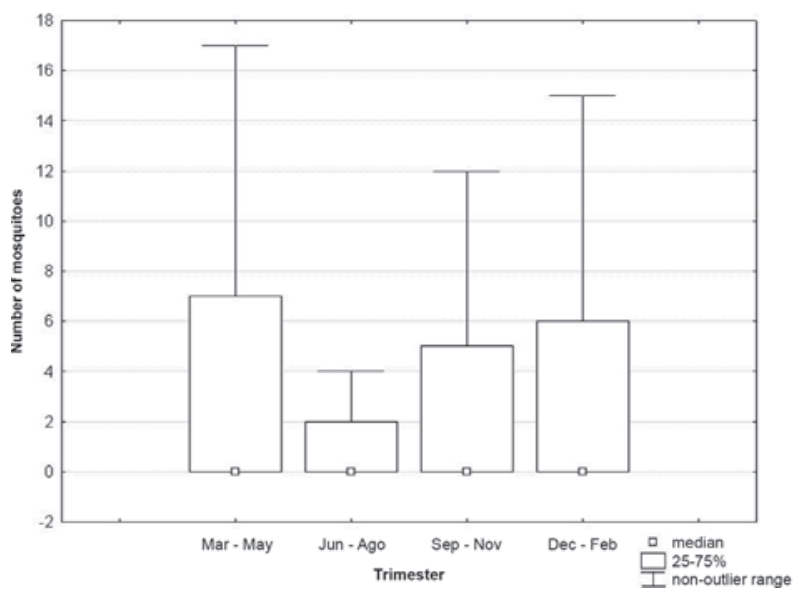

Fig 5: box-plot of numbers of immature mosquitoes collected in bromeliads by trimester, from March 2005 to February 2006, at Jardim Botânico do Rio de Janeiro.

2007) lead to the conclusion that these bromeliads are not important or even productive microhabitats for Ae. aegypti and, hence, do not need to be treated for dengue control. Additionally, we hypothesized that the occasional findings and frequency of Ae. aegypti in bromeliads in the modified environment may be correlated to high infestation levels in such an area as result of competition for ovipositing habitats. However the mosquito fauna in bromeliads maintained domestically in yards or houses, where Culex spp and Wyeomyia spp may be less common than in JBRJ, deserves to be investigated, because bromeliads have became popular houseplants in dengue endemic areas. Indeed, the results of this study of only one year in a single area may not represent outcomes in other urban localities where bromeliads, Ae. aegypti and dengue coincide in more disturbed habitats.

Also, it is known that the suitability of tank bromeliads for Ae. albopictus depends on bromeliad shape, e.g., Neoregelia spp being more suitable for development than Billbergia spp (Raban 2006). Moreover, our results may not apply to areas where bromeliads are not endemic yet are grown as ornamental plants in private gardens, such as Hawaii, where Ae. albopictus flourishes in bromeliad axils in the absence of competing native mosquito species (Yang et al. 2003).

\section{AKNOWLEDGEMENTS}

To Jair Rosa Duarte, for the suggestions in the design of this investigation, to Bruno Rezende Silva, for the bromeliads identification, to Marcelo Quintela Gomes, Kleber Soares de Sousa, Mauro Menezes Muniz, Marcelo Celestino dos Santos, Reginaldo da Silva Rego e Renato Carvalho de Andrade, for the support in the field work.

\section{REFERENCES}

Consoli RAGB, Lourenço-de-Oliveira R 1994. Principais mosquitos de importância sanitária no Brasil, Editora Fiocruz, Rio de Janeiro, 228 pp.
Corrêa RR, Ramalho GR 1956. Revisão de Phoniomyia Theobald, 1903. Folia Clínica Biol 25: 1-176.

Cotrim MD, Galati EAB 1977. Revisão da série Pleuristriatus do subgênero Microculex (Theobald, 1907) Diptera, Culicidae. Rev Brasil Entomol 20: 169-205.

Coutinho JO, Forattini OP 1962. Notas sobre Culicidae. Quarta contribuição ao estudo do subgênero Microculex com a descrição duma nova espécie. Studia Entomol 5: 209-234.

Cunha SP, Carreira Alves JR, Lima MM, Duarte JR, Barros LCV, Silva JL, Gammaro AT, Monteiro Filho OS, Wanzeler AR 2002. Presença de Aedes aegypti em Bromeliaceae e depósitos com plantas no município do Rio de Janeiro, RJ. Rev Saude Publica 36: 244-245.

David MR, Lourenço-de-Oliveira R, Maciel-de-Freitas R 2009. Container productivity, daily survival rates and dispersal of Aedes aegypti mosquitoes in a high income dengue epidemic neighborhood of Rio de Janeiro: presumed influence of differential urban structure on mosquito biology. Mem Inst Oswaldo Cruz 104: 927-932.

Forattini OP, Marques GRAM 2000. Nota sobre o encontro de Aedes aegypti em bromélias. Rev Saude Publica 34: 543-544.

Forattini OP, Marques GRAM, Kakitani I, Brito M, Sallum MAM 1998. Significado epidemiológico dos criadouros de Aedes albopictus em bromélias. Rev Saude Publica 32: 186-188.

Forattini OP, Toda A 1966. Notas sobre Culicidae. 11. Algumas espécies amazônicas de Microculex. Studia Entomol 9: 501-514.

Fouque F, Garinci R, Gaborit P 2004. Epidemiological and entomological surveillance of the co-circulation of DEN-1, DEN-2 and DEN-4 viruses in French Guiana. Trop Med Int Health 9: 41-46.

Frank JH, Stewart JP, Watson DA 1988. Mosquito larvae in axils of the imported bromeliad Billbergia pyramidalis in southern Florida. Fla Entomol 71: 33-43.

Lane J, Whitman L 1951. The subgenus Microculex in Brazil. Rev Brasil Biol 11: 341-366.

Lopez LCS 1997. Comunidades aquáticas em tanques de bromélias: zonação e sucessão, PhD Thesis, Universidade Federal do Rio de Janeiro, 132 pp.

Lopez LCS, D’Elias AMA, Iglesias R 1998. Fatores que controlam a riqueza e a composição da fauna aquática em tanques de bromélia Aechmea bromeliifolia (Rudge) Baker, na restinga de Jacarepiá Saquarema/RJ. Oecol Brasil 5: 91-100.

Lounibos LP, O’Meara GF, Nishimura N, Escher RL 2003. Interactions with native mosquito larvae regulate the production of Aedes albopictus from bromeliads in Florida. Ecol Entomol 28: 551-558.

Lourenço-de-Oliveira R 2008. Rio de Janeiro against Aedes aegypti: yellow fever in 1908 and dengue in 2008. Mem Inst Oswaldo Cruz 103: 627-628.

Lourenço-de-Oliveira R, Castro MG, Braks MAH, Lounibos LP 2004. The invasion of urban forest by dengue vectors in Rio de Janeiro. J Vector Ecol 29: 94-100.

Lourenço-de-Oliveira R, Heyden R, Silva TF 1986. Alguns aspectos da ecologia dos mosquitos (Díptera: Culicidae) de uma área de planície (granjas Calábria) em Jacarepaguá, Rio de Janeiro. V. Criadouros. Mem Inst Oswaldo Cruz 81: 265-271.

Lozovei AL, Silva MAN 1999. Análise comparativa entre métodos alternativo e convencional para amostras de mosquitos obtidos a partir de habitats fitotélmicos (Bromeliaceae) na floresta Atlântica, Serra do Mar, Paraná, Brasil. Rev Brasil Zool 16: 967-976.

Maciel-de-Freitas R, Marques WA, Peres RC, Cunha SP, Lourençode-Oliveira R 2007. Variation in Aedes aegypti (Diptera: Culici- 
dae) container productivity in a slum and a suburban district of Rio de Janeiro during dry and wet seasons. Mem Inst Oswaldo Cruz 102: 489-496.

Marques GRAM, Santos RLC dos, Forattini OP 2001. Aedes albopictus em bromélias de ambiente antrópico no estado de São Paulo, Brasil. Rev Saude Publica 35: 243-248.

Motta MA, Lourenço-de-Oliveira R 2005. Spilonympha. A new subgenus of Wyeomyia (Diptera: Culicidae) and description of a new species Wyeomyia aningae. Ann Entomol Soc Am 98: 838-852.

Natal D, Urbinatti PR, Taipe-Lagos CB, Cereti-Junior W, Diederich ATB, Souza RG, Souza RP 1997. Encontro de Aedes (Stegomyia) albopictus (Skuse) em Bromeliaceae na periferia de São Paulo, SP, Brasil. Rev Saude Publica 31: 517-518.

O’Meara GF, Cutwa MM, Evans LF Jr 2003. Bromeliad-inhabiting mosquitoes in south Florida: native and exotic plants differ in species composition. J Vector Ecol 28: 37-46.

Peryassú AG 1908. Os Culicídeos do Brasil, Instituto de Manguinhos, Typographia Leuzinger, Rio de Janeiro, 407 pp.
Raban RR 2006. Studies of Aedes albopictus: oviposition and larval density, development and interactions with Wyeomyia spp within exotic bromeliads in southern Florida, PhD Thesis, University of Florida, 127 pp.

Silva AM, Nunes V, Lopes J 2004. Culicídeos associados a entrenós de bambu e bromélias com ênfase em Aedes (Stegomyia) albopictus (Diptera; Culicidae) na Mata Atlântica, Paraná, Brasil. Iheringia Ser Zool 1: 63-66.

Varejão JBM, Santos CB, Rezende HR, Bevilacqua LC, Falqueto A 2005. Criadouros de Aedes (Stegomyia) aegypti (Linnaeus, 1762) em bromélias nativas na cidade de Vitória, ES. Rev Soc Brasil Med Trop 38: 238-240.

Yang P, Furumizo R, Tangalin L, Takekuma C, Hall KE 2003. Mosquito species (Diptera: Culicidae) breeding in bromeliad axils in the island of Kauai, Hawaii. Proc Entomol Soc Hawaii 36: 95-101.

Yanoviak SP, Lounibos LP, Weaver SC 2006. Land use affects macroinvertebrate community composition in phytotelmata in the Peruvian Amazon. Ann Entomol Soc Am 99: 1172-1181. 